\section{NGO/INGO CENTERED APPROACH: AN ALTERNATIVE APPROACH TO DEVELOPMENT}

\author{
Harihar Ghimire
}

A non-governmental organization (NGO) is a social organization motivated to work in sectors like religion, sociocultural, economic, educational, environment, women, children, etc, irrespective of any political ideology and belief. It is a nonprofit social institution established formally after registering at the Chief District Officer's office and affiliated with the Social Welfare Council (SWC) to work for the socially and economically backward people. In other words, apart from those governmental institutions working collectively for any social works, other organizations and institutions registered formally and lawfully at the government offices and which get renewed every year in district administration office are known as NGOs. These are voluntary, non-profitable, service oriented, and autonomous organizations. The objectives, thoughts and visions of these organizations may vary as per the targeted areas and their areas of concern.

In different countries various terms are used for NGOs, such as private voluntary organizations in the United States, civil organizations in Latin America, voluntary development organizations in Africa and peoples' organizations in some parts of Asia. The World Bank treats them as private or voluntary organizations. These different terminologies denote what is referred to as NGOs in Nepal. The Social Welfare Council

\footnotetext{
Mr. Harihar Ghimire is an Sociologist and has been associated with the Department of Sociology/Anthropology, Patan Multiple Campus, Patan T. U., in a Capacity of Assitant Lecturer.
}

(SWC) and NGOs Federation are the NGOs' apex bodies in Nepal.

Any organization that is registered in any country as per its rules and regulations is known as international nongovernmental organization (INGO). According to the resolution No. 288(x) passed on February 27, 1950 by the Economic and Social Council of the United Nations, those organizations not organized or inter-related through treaties are known as INGOs. The article 1 of the draft bill for international non-governmental organization treaty of the Union of International Association has pointed out the following characteristics of the INGOs:

a) Not having any objective of economic benefit,

b) Recognized at least by one nation,

c) To be an international forum,

The members of the INGOs might consist of individuals or national social organizations. The Prospectus/Constitution of the INGOs at the time of registration becomes the major guideline or directive for work. The INGOs do not become the subject of international law nor do their prospectuses or constitutions become formulated through international treaties. But, these organizations become the subject of national law. The INGOs can keep tangible and intangible assets and become the party in any judiciary agencies. In some countries like Belgium, the special laws and acts govern the formal status while in countries like England and France simple laws and acts govern the formal status included in references (Ghimire, 2001). The World Bank defines NGOs as "a wide variety of groups and institutions that are entirely or largely independent of governments, and characterized primarily by humanitarian or cooperative, rather than commercial objectives"

Globalization and development can be sustainable and beneficial to the people only if it is growing below as a process from inside to outside, based on principles of cooperation and complementarily, rather than imposed from outside and based on the relationship of dominance and competition. Such an inclusive process of globalization will not juxtapose the macro with the micro, local with the national and the material with the spiritual. 
Democracy, nevertheless, is only a necessary and not a sufficient condition for people focused development. This is because democracy, like the market, provides opportunity mainly to the socially strong and economically rich. The weak and the poor need to organize themselves for solidarity and collective action for betterment of their own opportunities and scope of action. This is where the NGOs/INGOs can play a catalytic role (Acharya, 1997).

Likewise, the experience of the $20^{\text {th }}$ century indicates that the state intervention cannot play positive and efficient role all over the nation. But, it could play positive and efficient role only in certain spheres of development initiatives. In the state centered approach, the process of development goes like this macro policy making, rules and regulation, formation and promotion of necessary social and physical infrastructure are the most appropriate spheres for state intervention. But, modern states, with a vast and rigid bureaucracy, are hardly capable of micro-policy reforms and power sharing. Further, states are often captured by the powerful and the wealthy and should maintain a political balance among various interest groups. Likewise, the market-centered approach provides opportunity mainly to socially strong and economically rich. Therefore, decision-making must be shifted from the state and the market to the people.

People's participation and empowerment of the people to control their own destinies should be the primary objective of development. This is possible only in NGO/INGO centered approach. This approach puts people at the center of the development efforts.

Ghimire (2001) has pointed out the following distinguished features of NGOs/INGOs:

a) Participatory planning: the local people are made to participate in the planning process right from formulating, to implementation and monitoring. It is thus participatory in nature.

b) Financial and technical assistance: they provide financial and technical assistance to the people. c) Development by the people and for the people: the programs are not directly implemented from the top level. The local people are also involved in various processes of the programs. The local people develop their own plans rather than other agents deciding on their needs.

d) Mass mobilization and creating awareness: all plans and programs are based on the involvement of the total mass. This process of involving the masses is effective in getting the results as awareness programs are also launched side by side.

e) People as an active and responsible agent of development: the local people get the feeling that they have to be involved in their programs as they are the ones to get the maximum benefit out of it. Hence, they feel more responsible and act as an active actor of development.

f) Income generation and empowerment: various income generating and empowerment programs are launched through NGOs/INGOs. All the people are involved in some development activities so that they can perform sustainable economic activities. For this to be effective, empowerment programs have to be meaningful and powerful tools for development. The local people are involved in the income generating activities by forming groups and users' groups.

g) Lacks long time perspective and low area coverage: the weak aspect of NGO/INGO programs is that they are usually for short term and cover only a small area. Most of the programs are stopped in the middle and all the investment in it becomes useless and less effective. It also does not help develop all areas of the country.

h) Welfare, basic human need and sustainability: the basic features or characteristics of NGOs/INGOs is that they focus on human welfare and basic needs. They work as non profit organizations and thus can be said to be of welfare motive. When the programs are handed over to the community after a lot of guidance and trainings, the 
programs seem to be sustainable and well functioned and people seem to take the responsibility of sustaining the programs as they are the ones who get the maximum benefit.

i) Priorities in rural area, remote area, poor, disabled and women: another distinguishing feature of NGOs/INGOs is that they work for the poor and people living in remote and rural areas and who are unable to improve their living standard. Disabled and people who are looked down upon by the society and government are the focus of NGOs/INGOs.

Government attempts at social mobilization in many developing countries attempted during the 1980s have mostly been a failure because they are top-down, service delivery oriented and often elite dominated. Cooperatives are an excellent example in this context. Further, such groups are not sustainable because they are organized in the first place for efficient delivery of services and not for self-help and self-development of the people. Capacity and efficiency in social mobilization is the greatest advantage the NGOs have. Many governments and donors are looking at the NGOs as a "means of getting benefits more directly and cheaply to the poor than governments have been able to accomplish on their own" (Korten, 1987).

INGOs/NGOs have been able to start from a small scale and expanding the scope of their activities slowly. NGOs/INGOs put people at the centre of the development discourse. Specially, they focus on poor, deprived women, children, marginalized groups etc. and their neat sectors are agriculture, health, education, environment etc.

\section{NGOs in Nepal}

The concept of NGOs is not new to the Nepalese people. Ancient social institutions like Guthi, Dhikuti, Parma, Dharmabhakari, Murdaguthi, Pujaguthi, Pati, Pauwa, Kuwa Rotating credit associations or self-help banks were run by different communities. Pati, Pauwa- a cottage was built by the local community with trees planted for shade which provided rest for tired travellers. Kuwa- wells were dug by the community for drinking water. And these initiatives can be considered now as NGOs in the Nepalese context.

"Shree Chandra Kamadhenu Charkha Pracharak Mahaguthi" is considered as the first NGO to be formally established in Nepal with the objective of social work. It was established in 1983 B.S. Similarly, the "Charkha Pracharak Sanstha" established in 1985 B.S by Tulshi Mehar Shrestha can also be regarded as an NGO. In 2004 B.S, social worker Dayabir Singh Kansakar had established a "Paropakar Aushadhalaya (Now known as Paropakar Sanshtha) regarded as an NGO, to help the physically incapacitated people. It was only after the political turnover during 2007B.S. that the NGOs were established in a formal and organized manner. In this regard, the first elected government in 2016 B.S adopted Association Registration Act 2016. This Act has profound importance in the history of the NGOs. But, while the people were still to know about the NGOs, and as the foundation of democratic government was in the process of setting up, Late King Mahendra adopted the Panchayat system on Poush 1, 2017 B.S by restricting establishment of political parties and organizations/institutions. Then the status of the nongovernmental organizations became weak. Still, during the time of Panchayat system social organizations like Paropakar, Red Cross, Nepal Jaycees etc were established. Likewise, the tradition of nominating the Royal Family members as the Chairperson of such organizations started (Ghimire, 2001)

From 2041/42 B.S, there has been a constant increase in the number of NGOs. There were 106 registered NGOs in the Kingdom of Nepal in 2041/42 B.S. and it increased to 191 before the establishment of democracy in 2046 B.S. In a real sense, the establishment or registration of NGOs increased rapidly after the political change of 2046 B.S. In 2049 B.S. Social Welfare Act was adopted. Then the SWC was established to monitor and coordinate and evaluate the works of national and international non governmental organizations. SWC keeps the updated records, helps and provides suggestions to the government regarding the plans and policies relating to the NGO/INGOs. 
There is no doubt that the NGOs are the actors of development. Therefore, NGOs have been recognized as important avenues for development promotion and for the first time in Nepal, the Eighth Five Year Plan (2049-2054 B.S) emphasized the importance of NGOs in enhancing production activity and socio-economic development. The current Five Year Plan (2054-2059 B.S) also has continued and recognized the important role of NGOs in development.

In the early 1990s, new policies were formulated which have made registration of NGOs much easier than in the past. As a result, the NGO sector is growing fast. There are three Acts which govern NGO/INGO activities in general. First, the Constitution of the Kingdom of Nepal 1990 ensures the right to open associations by all citizens. Second, the Social Welfare Act (1992) has established the SWC under the chairmanship of the Minister or Minister of State of Social Welfare which is to coordinate, facilitate, promote and mobilize NGOs for social welfare activities.

After the amendment of the Association Registration Act (1977), the new law provided for registration of NGOs, at all the CDO offices with minimum of restrictions. Any group of seven Nepali citizens may apply for registration specifying the name, address, and objectives of the organization. The NGOs are required to present audited accounts each year for the registration renewal of the organization.

Third, DDC and VDC Act (1992) tries to regulate DDC/VDC in coordinating the NGO/INGO activities in their respective areas to provide grants to NGOs and to enter into agreements with them for conducting programs and projects. VDCs are authorized to demand plans and programs from NGOs operating in their areas. NGOs are required to receive clearance for their projects from VDCs and through them, from DDCs. They are also required to work in close collaboration with the DDCs.

Presently, it is estimated that there are around 25 thousand NGOs working in the Kingdom of Nepal. But, according to the record of the SWC, there were 7,389 NGOs registered till $2055 / 3 / 23$. This number increased to 8,880 by
Ashad 2056 B.S. Likewise, the statistics shows 11,036 NGOs affiliated with the Council by the year 2057 B.S. The Council's 2058 B.S. record shows $12,388 \mathrm{NGOs}$ registered. If we look at the developmental practices in Nepal, we see that the national and international non governmental organizations have played a vital and key role. These organizations seem to be helping (being the partner in development activities) the government in development efforts as they are working and focusing in areas like the least developed regions, ethnic minorities, downtrodden women, children, etc. But, NGOs/INGOs cover only selected areas and sectors, it is unable to develop equally in all areas and sectors of Nepal. There seems to be the prevailing trend of stopping or leaving the programs in the middle of implementation and the practice of earning without work. Also, we find the lack of coordination between the government and the Social Welfare Council and between the national and the international Non-governmental Organizations.

\section{Kinds of NGOs in Nepal}

From a developmental perspective with the analysis of various NGOs, there are mainly national welfare oriented NGOs, professional NGOs and district/ village based NGOs.

1) National welfare oriented NGOs

Some welfare oriented NGOs operate on a national scale and have long histories. Nepal Red Cross Society, Family Planning Association of Nepal, Nepal Netra Jyoti Sangh, Nepal Anti T.B. Association are some examples of the welfare oriented NGOs in Nepal. They have developed strong institutional structures, for example, equipped hospitals and clinics. Such NGOs have local offices and programs in many parts of the country. Even though their annual expenditure is around a million dollars they miss long term visions.

\section{Nepal Red Cross Society (NRCS)}

Nepal Red Cross Society (NRCS) was established in 1963. It has a chapter in all the 75 districts of the nation. It is supported by more than 500 sub chapters and coordination committees and more than 432 thousand members (as of 1995 
AD). Program areas include community development including water and sanitation programs and community based first-aid programs: health services including blood transformation, health education, health service, family planning, ARI and AMS programs; disaster management including prevention, mitigation, preparedness, and rescue and relief activities.

\section{Family Planning Association of Nepal (FPAN)}

FPAN was established in 1959 A.D. It has grown to cover 27 districts. Its objectives include promotion of family planning as basic human right, empowering both men and women to make voluntary and informed choices and to support government family planning programs. Its activities are focused on family planning education, training, family planning promotion and services; mothers and child health services; and community development activities.

2) Professional NGOs

These kinds of NGOs are generally staffed with highly qualified personnel. Most of the professional NGOs are involved in research and action programs. Institute of Integrated Development System (IIDS), Rural self-reliance Development Centre (RSDC), Nirdhan, etc. are some examples of professional NGOs. Usually, an executive director is hired for day to day management of the organization.

3) District/Village based NGOs

These kinds of NGOs have often evolved out of the effort of a single charismatic leader. The leader is usually involved in various activities of the organization including fund raising, planning, coordinating as well as implementing. Their plan depends upon the availability of donation. Thus, long term visions are often missing and they often have to be guided by the interests of the donors. Social and health and environmental institutions are the examples of district/ village based NGOs.

\section{INGOs in Nepal}

INGOs have been recognized as important avenue for development promotion. A large number of INGOs operate in Nepal. The United Mission to Nepal (UMN) and Helvetas have been operating for more than four decades. Strategies of NGOs/INGOs of local intervention are similar. But, INGOs also function as donors to NGOs. Priority of funding and input components depend upon the objectives of each INGO and its leadership's vision, group awareness raising, group formation and credit are to all programs.

Most of the INGOs working as direct implementers has a fairly large number of staff and a complex organizational structure. CARE-Nepal works mostly as direct implementer of programs. UMN also implements programs by itself. It has a fairly large working network at community, district and central levels. Even though, Lutheran World Service (LWS) has a large establishment with more than 350 employees in its six project areas, it works in coordination with local partners in each of its project areas. LWS partners include national level NGOs like the Red Cross, the UN agency like UNHCR and grassroots development institutions.

In Nepal, INGOs have been working for the last four decades. The INGOs like UMN and Helvetas Nepal have been working for the development activities. According to the Social Welfare Council, there were 82 INGOs in the year 2056/57 B.S. working in Nepal. This number reached 103 in the fiscal year $2057 / 58$. The amount spent in various programs by these INGOs in $2057 / 58$ was Rs. 1.45 billion. In $2058 / 59$ the amount reached Rs. 2.4 billion.

\section{Weaknesses}

No principles, assumptions, and concepts can remain away from limitations and criticisms. The NGO/INGO approach to development also has certain limitations of its own though it seems working perfectly in the twenty-first century for the downtrodden and poor people. It also seems to be working hand in hand with the international governments to bring positive and constructive results. Still, this approach has following limitations and criticisms:

1) Lack of sustainability:

As programs rely upon international donors and technical supporters, such programs have to be stopped when the 
donors stop the fund or technical help. It does not in any case help sustainable development.

2) Covers limited sectors only or less coverage:

The NGOs cover only the limited selected areas and sectors as per their objectives and convenience. They do not help in equal development and in up-lifting the socio-economic conditions of all the people of a country.

3) Lack of local people's actual need in the programs:

Almost all the programs give priority and emphasis to the interests of the donors rather than giving priority to the actual felt needs of the targeted people. It does not in the long run help solve the problems of the needy people.

4) Lacks social welfare motive:

Though the NGOs promise to work with the social welfare motive, most of them operate with the objective of making profit. This will not help in reaching the objectives as targeted.

5) Lack of execution of set goals:

The records of all the NGOs remain in the CDO office and in the $\mathrm{SWCl}$, but there is a lack of a mechanism to monitor and evaluate the works done by those organizations. Only some NGOs are practically in existence and working as per their objectives. This trend will certainly not lead to positive changes in the society.

6) Political affiliation (affiliation to certain political parties):

Many NGOs in the country seem to be directly affiliated to one particular party. They follow the political directives given to them by their leaders and work for the interests of such parties. Many NGOs have been opened by a direct link with international traders and they are mobilized to preach on religion.

7) Lack of special provision to establish a NGO:

As any person can establish NGOs, and there is no provision or process of sustaining the established NGOs, there remains a trend of dismissing them at any time they like.

8) Lack of coordination:
There is a lack of coordination between the government and the SWC and between the INGOs and NGOs. It creates misunderstandings and duplication of work within such organizations. The government seems to be losing even the legal control and monitoring of the NGOs and INGOs. The SWC which has the responsibility of guiding the NGOs/INGOs in right track is unable to do so due to lack of infrastructure and other capabilities.

9) Lack of monitoring:

There is no mechanism to evaluate, supervise and guide the NGO/INGOs working throughout the country. Hence, some organizations seem to be gaining a national status without performing designated and set goals. This trend does not help motivate hard working organizations as they always remain in shadow.

10) Differences in Setting of priorities:

Some of the INGOs seem to be giving priority and attention to the interests of their own country rather than focusing on the interests of the local people.

11) Change (modification) in local culture and technology:

The local problems may not be solved as INGOs introduce and implement technologies not suitable to the necessities of the local people. It lacks the application of suitable technologies in the existing socio cultural and geographical environments and conditions. The local culture, tradition, practices and technologies also either change or modify or become extinct.

12) High expenditure in remuneration of foreign experts:

The INGOs employ foreign citizens as local consultants. This leads to allocating most of the financial resources to the foreign employees which should have been allocated to the development projects. The foreign employees may not be familiar with the local problems and the appropriate method of solutions.

13) Not able to reach the targeted people:

With some exceptions, most of the INGOs have not been able to reach down to the real and actual targeted groups 
and poor people who are in need of help. They are unable to mobilize the resources properly.

14) Lack of accountability:

The INGOs and NGOs are not accountable to any agencies in practice. They ought to be accountable to the working groups while doing work and accountable to the SWC too.

15) Lack of transparency:

Regarding the funds and financial mechanisms, INGOs/NGOs are not transparent. Many INGOs have denied giving their statements of annual income and expenditures to the SWC.

\section{Conclusion}

The NGOs/INGOs are non-profitable institutions. NGOs mostly focus on sectors like: agricultural expansion, irrigation, forestry, drinking water, basic and primary education, primary health care etc while INGOs focus on awareness raising, group formation and credit, area development, health and humanitarian assistance etc

There is no doubt that NGOs/INGOs play a pivotal role in nation building, but, due to the lack of sustainability and accountability the beneficial and effective results have not materialised. Channel of their funding and financing mechanisms are not transparent. For solving this problem the government should be able to monitor, guide and facilitate their activities to empower the people.

\section{REFERENCES}

Acharya, M. Non-government Organization (NGOs)- Led Development in Nepal, pp. 69-99, Occasional Papers in Sociology and Anthropology, Published by Central Department of Sociology and Anthropology, Kirtipur, 1997.

Bhattachan and Mishra (Editors): Developmental Practices in Nepal, Published by Central Department of Sociology and Anthropology, Kirtipur, 1997.

Bongartz, Heinz and Dahal, D.R. Development Studies, Self Helf Organization. NGOs and Civil Society, NEFAS and FES, 1996.
CEDA. Role of NGOs in National Development, Seminar Report, 1992.

Chambers, Roberts, Whose Reality Counts, Bath, United Kingdom : International Technology Publication, Bathpress, 1992.

Chand, Diwakar. Development Through Non-government Organization in Nepal. India Institute for Social Development Research and Social Services, 1991.

Chetri, Ram, B. Rotating Credit Association in Nepal: Dhikuri as Capital, Credit, Saving and Investment. pp. 449-454. Human Organization, Volume 54, November 4, 1995.

Franz, Telmo Rudi. The Role of NGOs in strengthening of Civil Society in World Development, Volume 15, Supplement, pp. 39-49, 1987.

Ghimire, H.H., Nepalma Vikas Ka Prayasharu (Developmental Practices in Nepal) Sajha Prakashan, Kathmandu, 2001.

Himal South Asia (Himalayan Magazine), Published Monthly by Himal Association, Lalitpur, Nepal.

Korten, David. Third Generation NGO Strategies : A Key to People Centered Development, PP. 145-159, in World Development, Vol. 15, Supplement, 1987.

Ministry of Law and Justice: NGO Act (with post Ammendments) Kathmandu, Ministry of Law and Justice, 1977.

National Planning Commission. The Ninth Five Year Plan, Kathmandu, National Planning Commission, 1998.

Occassional Papers (Series of Issues) Published by CDOSA (Kirtipur), DOSA (Patan Multiple Campus), APROSE, ICIMOD, etc.

Rhian, Hill and Tamang Deepak. NGO's in Nepal: Change and Challenge, Kathmandu, SEARCH, 1990. 